\title{
How commitment influences students' conversations about higher education
}

\begin{abstract}
Commitment and word-of-mouth communication are important relational ideas: commitment a central and defining aspect of relationships; word-of-mouth a key relational outcome. This research examines the relationship between commitment and word-of-mouth communication within the context of higher education. The study tests a new conceptual framework which explains the impact of students' commitment on students' intentions to emit word-of-mouth. It uses structural equation modelling to analyse data from undergraduate students studying at four UK HEIs. Interestingly whilst students feel stronger levels of affective commitment towards their university than towards their academic tutors, it is the affective commitment towards academics which has the greatest influence on students' intentions to talk positively about their university experience.

This research corroborates extant studies which articulate the importance of affective commitment as a driver of positive word-of-mouth, highlighting the critical contribution of affective commitment directed towards people. If Universities are looking to generate positive stories about the experiences they offer, then the relationships between students and academics are a likely determinant of success.
\end{abstract}




\section{Introduction}

Universities seek to attract and retain students who speak positively about their experiences of higher education to other students, prospective students, friends and family. We know that word-of-mouth influences the university application process and the choice of modules once students are at university (Patti and Chen, 2009; Taylor, 2009; Li and Wang, 2010; Herold and Sundqvist, 2013; Greenacre, Freeman, Cong and Chapman, 2014; Sipilä, Herold, Tarkiainen and Sundqvist, 2017; Herold, Tarkiainen and Sundqvist, 2017). Previous studies have identified commitment as an important driver of word-of-mouth communication within a range of contexts (Harrison-Walker, 2001; de Matos and Rossi, 2008; Beatty, Reynolds, Noble and Harrison, 2012; Breitsohl and Ruhle 2016; Fazal-e-Hasan, Lings, Mortimer and Neale 2017). This is the first paper to examine the relationship between a range of forms and foci of commitment and word-of-mouth within the context of higher education (HE).

This paper is underpinned by a relational perspective of higher education. It draws from scholarship which has informed the development of relationship marketing, often within broad service contexts, sometimes within HE. Over the past two decades, since Morgan and Hunt's (1994) seminal work articulating the key tennets of relationship marketing, a series of authors (e.g. Hennig-Thurau, Langer, and Hansen, 2001; Helgesen, 2008; Bowden and Wood, 2011; Raciti, 2012; Wardley, Belanger and Valorie, 2013; Bowden, 2013; Li, 2014; Southcombe, Fulop and Carter, 2015; Chen, 2016; Fazal-e-Hasan et al., 2017) have brought a relational perspective to the context of higher education. There is a sense (Wong and Wong, 2012; Carvalho and de Oliveira Mota, 2010) that relational ideas are worthy of further research within HE. Hennig-Thurau et al.'s (2001) work, examined the impact of a range of relational antecedents on student loyalty with commitment as a central aspect of their model. 
This study re-engages with commitment and couples commitment with a key relational outcome, word-of-mouth communication.

It is notable that much of the research examining relational concepts within HE adopts a case-study approach (e.g. Kara and de Shields, 2004; Helgesen and Nesset, 2007; RojasMendez et al., 2009; Hayes, Ruschman and Walker, 2009; Southcombe et al., 2015). This study seeks to draw evidence from a broader range of institutions.

In summary, this research seeks to contribute new knowledge about the relationship between commitment and word-of-mouth communication within the context of higher education. Explicitly the research aims to examine:

What is the impact of undergraduate students' commitment on word-of-mouthcommunication about the HE experience?

The study commences with the development of a new conceptual framework which seeks to explain the relationship between word-of-mouth communication and commitment. It articulates constructs of commitment which bring together calculative, affective and normative dimensions of commitment, with foci for commitment appropriate to the context of higher education. Commitment balance (author/s, 2019) is an innovative aspect of the proposed framework.

Exploratory and confirmatory factor analysis are used to develop the constructs and the framework itself is empirically tested and analysed using structural equation modelling. A final adapted framework is proposed with implications for HE around the importance of student-academic relationships and the need for institutions to invest in people and environments which support these relationships.

\section{Theoretical background}




\section{Word-of-mouth communication.}

Word-of-mouth communication is the storytelling of everyday life. Word-of-mouth can be conceived as conversational stepping stones, connecting people to organisations and each other. Students' conversations permeate their experiences of HE; mutters within the lecture theatre, animated conversations in the café, social media posts, well everywhere.

This study draws from well-established and cited work outside HE (Arndt, 1967; Westbrook, 1987; Harrison-Walker, 2001) together with ideas from Patti and Chen (2009) developed in their study of Australian higher education, to define word-of-mouth in the context of HE as:

Informal, interpersonal, planned or spontaneous non-commercial communication about higher education experiences, participants and institutions (including information guidance, subjective personal experience and personal advice) originating from students.

Conversations are between individuals (one-to-one or one-to-many), include face-toface and online communication and are about higher education experiences, participants (academics, fellow students) or institutions (universities). Such communication, is directed to fellow students and/or external audiences (strong and weak ties) and is essentially noncommercial in nature. Conversations with academics or the institution more broadly, are considered here to be feedback, rather than word-of-mouth and are therefore not the focus of this study.

Whilst this study examines word-of-mouth intentions, in line with Fullerton (2005, 2011), it acknowledges Wangenheim and Bayon's (2003) caution that word-of-mouth intentions may not be a good predictor of word-of-mouth behaviour. However, intentions whilst reliant on self-reports and therefore potential distortion, do benefit from avoiding 
reliance on recall.

\section{Commitment.}

Commitment is arguably the central character within the narrative of relational exchange. It is an important driver of word-of-mouth communication and thus at the heart of this study. This work draws upon early scholarship (Allen and Meyer, 1990; Moorman, Zaltman and Despande, 1992; Morgan and Hunt, 1994) and previous work by the author/s (2019) to define commitment as:

an ongoing connection, based upon a desire, need or obligation to maintain that connection and a preparedness to invest in perpetuating that connection.

Commitment is the perpetuation of an ongoing sense of connection, with an institution such as a university, or people such as academic tutors. This study proposes that this ongoing connection plays an important role in driving students' intentions to speak positively about their experiences of higher education. The sense of an extended, ongoing partnership justifies students' investment of effort and their personal credibility supporting higher education through positive word-of-mouth.

One limitation of current thinking about commitment is its focus on commitment as an absolute rather than relative construct. This paper sees the notion of mutuality or balance to be central to the dynamics of commitment. This idea is evident within Gundlach, Achrol and Mentzer's (1995:78) work highlighting the importance of mutual commitment, and is developed further by author/s (2019).

This paper argues that as HE demands increasing commitment from students, there must be a match in authentic and demonstrable commitment to students evidently reciprocated from students' relational partners. As institutions seek to encourage commitment from students, they must be prepared to demonstrate high levels of reciprocal commitment to their students. Indeed, commitment balance reflects the pulse of reciprocity which energises 
relational exchange (author/s, 2019). Whilst scholarship repeatedly acknowledges the importance of mutuality (e.g. Morgan and Hunt, 1994; Gundlach et al., 1995) the notion of commitment balance is a new concept, seen as the extent to which students perceive that the commitment they feel is equally matched by the reciprocal commitment they perceive to be emanating from the relational partner (author/s, 2019). This paper suggests that commitment balance may have a range of positive outcomes including word-of-mouth communication.

\section{Foci of commitment.}

Jones, Taylor and Bansal's (2008) work in the service sector established that commitment can be experienced to multiple targets (the organization, employees and employees as friends). Beatty et al. (2012:311) conclude their study of commitment and voice with a recommendation that 'future studies should also specify the target of the commitment'. Multiple foci for commitment are appropriate for the HE context (Hennig-Thurau et al., 2001) and are developed within this study.

It is striking to note how previous commitment-orientated constructs within HE largely ignore academics. Such an omission seems more apparent, given the work by Hansen et al. (2003) outside the context of HE, which highlighted the importance of commitment towards front-line employees for customer retention.

Commitment to academics is worthy of exploration and a unique aspect of this study. Commitment towards the institution is an additional focus and has been acknowledged in previous studies which examine commitment in HE (e.g. Hennig-Thurau et al. 2001; author/s, 2019).

This paper argues that alongside the external foci for commitment, higher education brings with it an opportunity to consider a more internally-orientated focus - the student 
him/herself and their learning endeavours. This is similar to Hennig-Thurau et al.'s (2001) 'goal commitment'.

Thus, this study adopts three foci for students' commitment: student-as-learner; their institution; and the academics with whom they study. It combines these foci with the three dimensions of commitment, affective, normative and calculative, originally proposed by Allen and Meyer (1990) and established within studies of commitment within a range of contexts.

Previous studies examining normative commitment in relation to word-of-mouth (Gruen et al., 2000; Fullerton, 2011; Beatty et al., 2012) employed a focus of normative commitment towards the organisation. However, normative commitment in this context is argued to be directed towards the internal focus of student-as-learner. That is, the sense of ongoing obligation, duty, morality and responsibility is largely directed towards students themselves as learners and achievers. Normative commitment having an internal rather than external focus, is an innovative aspect of this study.

\section{Connecting commitment to word-of-mouth communication.}

Whilst commitment has been an increasing focus of study within academic scholarship (e.g. Hansen et al., 2003; Sharma et al., 2005; Lacey et al., 2007; Evanschitzky et al., 2011; Beatty et al., 2012; author/s, 2019) and many scholars are interested in the consequences of commitment (e.g. Hansen et al., 2003; Gustafsson et al., 2005; Evanschitzky et al., 2011) there is a growing body of work which explicitly examines commitment as an antecedent of word-of-mouth communication (e.g. Harrison-Walker, 2001; Brown et al., 2005; Fullerton, 2005; Fullerton, 2011; Beatty et al., 2012; Han and Ryu, 2012; Sun et al., 2013; Breitsohl and Ruhle, 2016; Fazal-e-Hasan et al., 2017) indicating scholars' interest in this relationship. Just one of these studies has been conducted within the context of 
education. Fazal-e-Hasan et al. (2017) found that affective commitment towards the organization was a mediator between gratitude and word-of-mouth communication within the HE sector in Pakistan. This research seeks to address this opportunity to develop knowledge about forms and foci of commitment and how they relate to word-of-mouth communication within the context of UK higher education.

We move into this study with corroborative evidence outside the HE context, that affective commitment has a positive impact upon word-of-mouth communication, expressed as advocacy intentions (Brown et al., 2005; Fullerton, 2005; Fullerton, 2011; Sun, Ayoun, and Calhoun, 2013, Breitsohl and Ruhle, 2016), word-of-mouth activity and word-of-mouth praise (Harrison-Walker, 2001) and positive word-of-mouth behaviour (Brown et al., 2005; Beatty et al., 2012). Such evidence would support hypotheses that the constructs associated with affective commitment (affective commitment towards academics; affective commitment towards institution) would be positively related to constructs concerning advocacy (intention to emit positive word-of-mouth communication).

Evidence from previous studies (e.g. Harrison-Walker, 2001; Beatty et al., 2012; Sun et al., 2013) repeatedly demonstrates that there may be either a weak, negative relationship between calculative commitment (continuance commitment, high-sacrifice commitment) and advocacy, or no relationship at all. Harrison-Walker (2001) found no relationship between high-sacrifice commitment and word-of-mouth. Sun et al.'s (2013) study within an organisational context, found that calculative commitment had the weakest impact on advocacy intentions of the three dimensions of commitment. Fullerton's (2005) work suggests that continuance commitment may diminish the impact of affective commitment upon advocacy. Fullerton (2011) found a significant negative relationship between continuance (calculative) commitment and advocacy intentions. Beatty et al. (2012) found that calculative commitment had a weak negative relationship with positive word-of-mouth. 
Literature analysing the relationship between normative commitment and word-ofmouth is sparse. Fullerton's (2011) study was the first to explicitly focus upon the relationship between normative commitment and advocacy intentions, finding a weak positive relationship between the two constructs in two of the three sectors studied. In contrast, Beatty et al. (2012) found evidence to support their hypothesis that normative commitment had no relationship with positive word-of-mouth. Thus, evidence that normative commitment drives word-of-mouth communication is very limited; this will be the first study to examine this relationship in the context of HE.

\section{Conceptual framework}

The proposed conceptual framework includes relationships between commitment constructs and positive word-of-mouth intentions (see figure 1). A series of hypotheses define this framework.

First, this research proposes that students experience affective commitment towards the academics (AFFAC) with whom they have worked over the period of their study and that this is a driver of students' intentions to speak positively about their experiences of higher education (PWOM). Such affective commitment is linked to notions of ongoing interactions with academics characterised by enjoyment, caring and inspiration. The affective commitment experienced towards academics generates a desire to reward those academics directly or indirectly through conversations which articulate the positive interactions students have experienced with academics. We have seen that the relationship between affective commitment and word-of-mouth is evidenced in a series of extant studies (e.g. HarrisonWalker, 2001; Beatty et al., 2012; Breitsohl and Ruhle 2016) outside the context HE. Most recently Fazal-e-Hasan et al. (2017) have examined affective commitment as a mediator 
between gratitude and word-of-mouth within HE. Thus, this is a replication of previous work with the new element of a commitment-focus on people. The proposed relationship is articulated within hypothesis 1 .

\section{Hypothesis 1:}

Students' affective commitment to academics is positively and significantly* related to intention to emit positive-word-of-mouth communication.

$*_{w h e r e ~} p<.001$

This research proposes that students' intentions to speak positively about their HE experiences are also driven by students' affective commitment towards their University. Affective commitment towards institution (AFFIN) comprises a sense of an ongoing connection with the University within which students study, characterised by belonging, inspiration, identification, caring and pride. Again, the expectation is that these feelings associated with affective commitment provide positive stories to be shared and result in students' attempts to reward the institution through word-of-mouth. This is again a replication of previous studies which have examined the relationship between affective commitment towards an organisation and word-of-mouth outside the context of HE (e.g. Brown et al., 2005; Fullerton, 2011; Sun et al., 2013). In particular, it replicates Fazal-eHasan et al.'s (2017) study of affective commitment and word-of-mouth within HE. Despite this replication it is an important relationship to include within a framework which seeks to explain how commitment influences word-of-mouth in HE. It allows comparison of relationship strengths between commitment constructs and word-of-mouth. Hypothesis 2 articulates this relationship.

Hypothesis 2:

Students' affective commitment towards the institution is positively and significantly* related to intention to emit positive word-of-mouth communication. 
This paper proposes that students experience calculative commitment towards their University (CALIN) and this will undermine positive word-of-mouth. Calculative commitment is principally evidenced by the perceived costs (financial and social) of leaving the institution during students' period of study. This more negative orientation of commitment based on the penalty of departure, will result in students with-holding positive stories in an attempt to assert some control in a situation characterised by students' perceived lack of power to exit. Withholding positive stories may be a result of direct or indirect attempts to penalize the institution for these perceived costs of departure, and these perceived costs may inhibit positive experiences and therefore positive stories to share. The relationship between calculative commitment and word-of-mouth communication has been studied within a small number of studies (Harrison-Walker, 2001; Fullerton, 2005; Fullerton, 2011; Beatty et al., 2012) and thus there is a replicative element to this hypothesis, however this is the first examination of this relationship within higher education. Hypothesis 3 articulates the proposed relationship.

\section{Hypothesis 3:}

Students' calculative commitment towards the institution is negatively and significantly* related to intention to emit positive word-of-mouth communication.

This research proposes that students may experience normative commitment towards themselves as learners (NORMSELF) and this will increase positive word-of-mouth. This construct is distinctive as it is internally-focused, nevertheless its ongoing nature and characteristics of duty, loyalty, obligation and moral responsibility reflect the nature of commitment. There is some similarity here to Hennig-Thurau et al.'s (2001) goal commitment: the focus of commitment is an achievement rather than a tangible object. It is 
proposed that such normative commitment will generate positive word-of-mouth as students' commitment to themselves to succeed, increases preparedness to speak out about experiences which they feel enhance their intended success. Students are aware that their positive wordof-mouth can contribute to their future success; their normative commitment to self-aslearner generates positive conversations which will enhance their achievement as students are connected with a successful entity. A small number of studies (Fullerton, 2011; Beatty et al., 2012) have examined the relationship between normative commitment and word-of-mouth communication, adopting external foci for commitment. This is the first study of the relationship between normative commitment and word-of-mouth within the context of $\mathrm{HE}$ which is articulated in hypothesis 4.

Hypothesis 4:

Students' normative commitment towards self-as-learner has a positive and significant* relationship with intention to emit positive word-of-mouth communication.

This research proposes that a sense of commitment balance and mutuality is a positive aspect of students' experiences of HE and will increase intentions to speak positively. Commitment balance (COMBAL) implies perceptions of ongoing and balanced reciprocal exchange between students and their institution. A sense of imbalance within the studentinstitutional relationship will make students less likely to speak positively about their experiences within HE as they seek to penalize or at least not to proactively help an institution which they perceive is not reciprocating equitably. The expectation is that low commitment balance will powerfully undermine positive word-of-mouth; more so than high commitment balance stimulates positive word-of-mouth. Therefore, students' perception of balance of commitment between them and their institution will enhance the likelihood of 
students engaging in positive word-of-mouth communication. This is the first examination of the relationship between commitment balance and word-of-mouth within any research context and thus offers entirely new insights. The proposed relationship is articulated within hypothesis 5.

\section{Hypothesis 5:}

Students' perceptions of commitment balance between students and institution are positively and significantly* related to intentions to emit positive word-of-mouth communication.

\section{Figure 1: Proposed conceptual framework.}

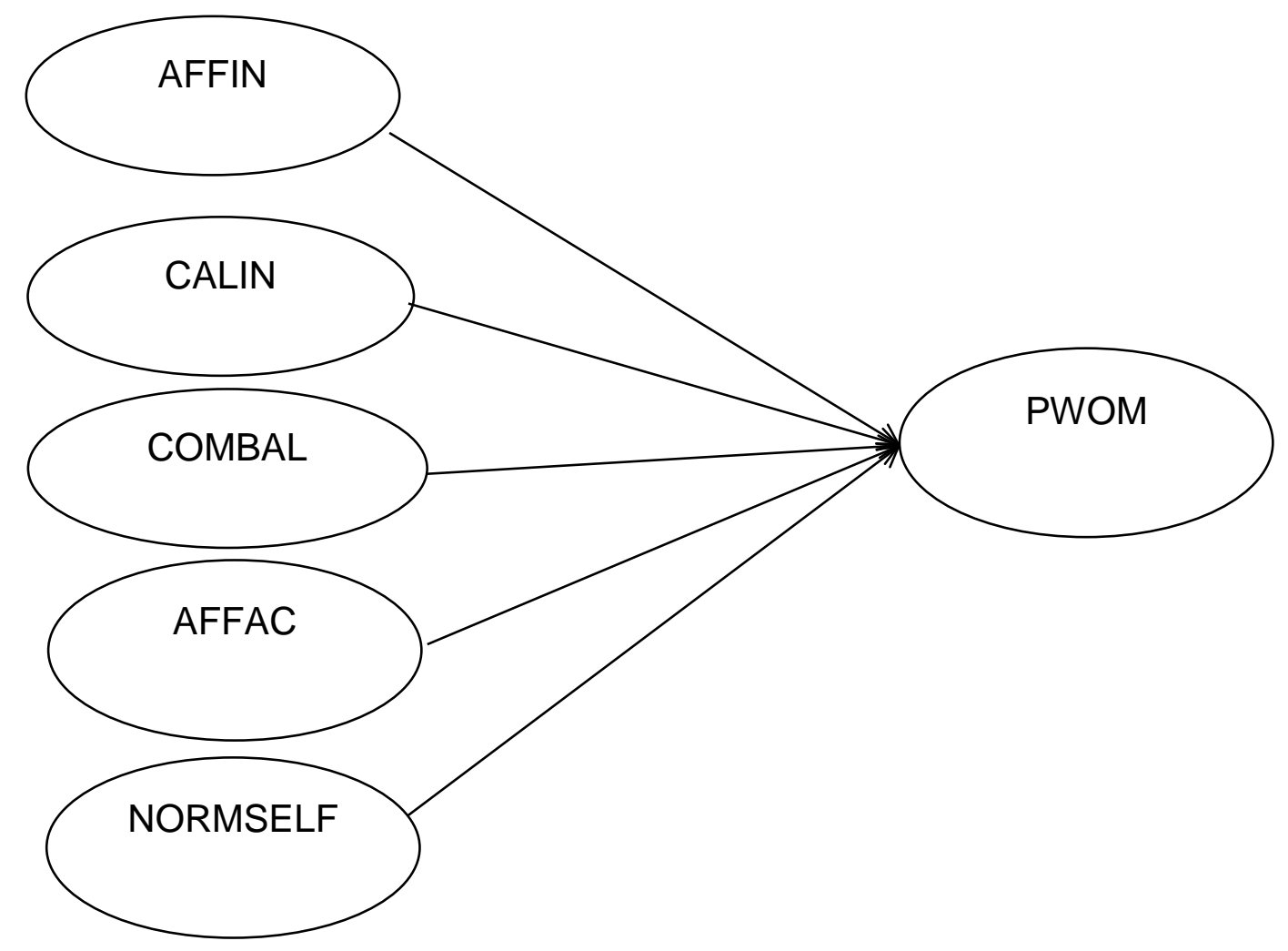

Empirical study will determine whether the proposed relationships exist, the relative strengths of relationships and whether the conceptual framework is a good explanation of the impact of commitment on word-of-mouth communication in the context of HE. 


\section{Method}

The theoretical model was devised to explain relationships between students' commitment and word-of-mouth intentions, in order to address the research aim:

What is the impact of undergraduate students' commitment on word-of-mouthcommunication about the HE experience?

Two research objectives were identified:

1. To assess the extent of undergraduate students' experiences of commitment within higher education;

2. To determine the relationship between students' commitment and their intentions to emit positive word-of-mouth communication about higher education.

The research population comprised full-time undergraduate students studying at modern UK Universities. A quantitative survey method was adopted to reflect the demands of the research aim and objectives. A largely purposive sampling approach used gatekeepers to access the student sample.

The research tool comprising questions measuring constructs within the conceptual framework, was distributed through email, web-based and face-to-face communication. Responses were received from 1474 students, studying at four universities, of whom 1129 completed all questions. Respondents were well distributed across year groups. Females were over-represented in the sample, accounting for $62 \%$ of respondents.

Each participant completed the survey on one occasion only. Podsakoff et al. (2012) note that although this is common practice, such an approach can introduce method bias. Whilst there was no temporal separation (Podsakoff et al., 2012) between responses relating to independent and dependent constructs, the questionnaire layout provided proximal 
separation between dependent and independent constructs which reduced potential method bias (Podsakoff et al., 2012). Questions relating to word-of-mouth communication and commitment were located within separate sections of the survey. A Harman's single factor test was conducted on the data, and showed a high level of variance accounted for by a single factor $(39.8 \%)$ but less than the 50\% Gaskin (2011) advises to be of great concern. Nevertheless, common method bias would be considered within the data analysis.

Tests for collinearity were conducted using Spearman's rho (Cohen et al., 2011). No correlations were equal to or above 0.8 , thus the research could proceed to structural equation modelling with the reassurance that the independent and dependent variables were not highly correlated. Scale reliability tests generated a Cronbach Alpha for the aggregate of independent variables of .912. All scales had Cronbach Alpha over .7 except calculative commitment towards institution (.670). Factor loading using principal components analysis (maximum likelihood; promax rotation) generated satisfactory loading onto six factors. The Kaiser-Meyer-Olkin (KMO) measure of sampling adequacy was good at 0.928 and significant at $<.0001$.

In summary, a substantial number of undergraduate participants, reasonably well distributed across year group and gender, provided data through an online survey. Whilst proximal separation was used to reduce concerns about common method bias, the lack of temporal separation in respondents' consideration of measures related to independent and dependent variables, means that common method bias should be considered within the analysis.

\section{Findings}

\section{Research objective 1}

To assess the extent of undergraduate students' experiences of commitment within higher education. 
Analysis of modes and means indicated that commitment was evident within students' assessment of HE and that the extent of those evaluations varied depending on the dimension and focus of commitment. Figure 2 presents a hierarchy of the commitment reported within this study drawn from an aggregate of responses to the measures associated with each form of commitment. Unsurprisingly the most strongly reported form of commitment was focused on students themselves as learners. However, with modes of 7 for each of the three measures of the normative commitment to self-as-learner construct, the lack of variation within this construct might impede a relationship between this and the dependent variable, as the lack of a wide scale range constrains its ability to impact the dependent variable in different ways. The paucity of cases with low levels of normative commitment towards students-as-learners, means that there would be little evidence available to examine whether low normative commitment has a positive or negative impact on word-of-mouth. 
Figure 2: Extent of commitment within higher education.

\begin{tabular}{|c|c|c|c|c|c|}
\hline $\begin{array}{c}\text { Form and focus of } \\
\text { commitment. }\end{array}$ & Modes & $\begin{array}{c}\% \\
\text { agreeing with } \\
\text { statements }\end{array}$ & $\begin{array}{c}\text { Mean } \\
\% \\
\text { agree }\end{array}$ & $\begin{array}{c}\% \\
\text { disagreeing } \\
\text { with } \\
\text { statements }\end{array}$ & $\begin{array}{c}\text { Mean } \\
\% \\
\text { disagree }\end{array}$ \\
\hline $\begin{array}{l}\text { Normative } \\
\text { commitment towards } \\
\text { self-as-learner. }\end{array}$ & $7,7,7$ & $88,94,95$ & 92 & $4,4,4$ & 4 \\
\hline $\begin{array}{l}\text { Affective commitment } \\
\text { towards institution. }\end{array}$ & $6,6,6,5,5$ & $66,66,78,80,65$ & 71 & $14,16,10,8,16$ & 13 \\
\hline $\begin{array}{l}\text { Affective commitment } \\
\text { towards academy. }\end{array}$ & $4,5,5,5,5$ & $66,52,67,71,66$ & 64 & $11,20,11,11,17$ & 14 \\
\hline $\begin{array}{l}\text { Calculative } \\
\text { commitment towards } \\
\text { institution. }\end{array}$ & $4.6,7,7$ & $55,65,51,63$ & 59 & $27,16,27,14$ & 21 \\
\hline
\end{tabular}

Key: 1 strongly disagree; 7 strongly agree.

The data aggregated from the measure level suggested that calculative commitment was experienced less than affective commitment. Affective commitment towards institution was more extensive than affective commitment toward academics; calculative was the least reported form of commitment. This was surprising given students' social and financial investments and implications for the perceived costs of leaving HE.

In summary, there was evidence of undergraduates' commitment within HE. Most strongly reported was moral commitment towards students themselves as learners. The most 
strongly reported commitment to an external focus was affective commitment towards students' institution. Affective commitment towards academics was reported by fewer students. Calculative commitment towards the institution was evident amongst respondents, but appeared to be the least extensively reported form of commitment. The lower level of affective commitment experienced towards academics than towards institution, may reflect the variation experienced towards academics; high for some academics; low for others. This could be further unpacked in future studies.

Responses were analysed by participant characteristic, using Mann-Whitney U and Kruskall-Wallis tests, both designed for non-parametric, non-continuous data; Mann-Whitney comparing two categories (gender); Kruskall-Wallis comparing three or more categories (year of study). No measures were evaluated differently by gender or year group (significance p.<0.05). This is surprising and therefore interesting, as the different characteristics and demands of study during an undergraduate degree, might lead us to anticipate that students' commitment varies over the period of study. Thus, the hierarchy of commitment (figure 2) appears to be appropriate for both genders and across year groups.

\section{Research objective 2}

To determine the relationship between students' commitment and their intentions to emit positive word-of-mouth about higher education.

Research objective 2 was tackled using structural equation modelling; first building a measurement model, then a structural model to allow testing for model fit, relationship strength and significance. 


\section{Measurement model.}

Using a measurement model, confirmatory factor analysis (CFA) generated strong and significant estimates across all measures except two of the four for calculative commitment. Model fit assessments were conducted on the CFA and repeated with the addition of error co-variances as suggested by Byrne (2010). Error co-variances were identified from modification indices >100 (using AMOS version 23), accompanied with theoretical justification. So, each additional co-variable could be explained conceptually. Similarly, MIs between latent variables were analysed for size and theoretical support. Covariances were added between AFFIN and COMBAL (MI 534), AFFAC and COMBAL (MI 282) and AFFAC and AFFIN (MI 316). Again, these additional co-variances could be supported by a theoretical link between the latent variables; AFFIN and COMBAL were linked by a focus on institution; AFFAC and AFFIN were linked by the nature of affective commitment, both concerning feelings of caring, belonging and inspiration; AFFAC and COMBAL were the least theoretically connected as they had different foci, but still had a sense of the dedication associated with commitment at their heart. This added co-variance underpinned by a less powerful theoretical connection is therefore a potential limitation to the analysis and the validity of the data.

CFA and model fit tests indicated that the error co-variances improved model fit and moved the measurement model close to the realms of good fit with chi-square 1685 with 282 degrees of freedom, a CFI of 0.913 compared to Hair et al.'s (2010) target of 0.92 and a RMSEA of 0.066, within the target of below 0.08 (Hair et al. 2010). A significant difference was identified between the nested models as $p<0.001$. It is however acknowledged that these additional error and latent variables co-variances improved model fit and may therefore overestimate the explanatory power of the framework with implications for validity of the analysis. 


\section{Structural Model.}

Once the measurement model had been established as appropriate, the structural model was built to reflect the five hypothesised relationships. Evidence would be sought to dismiss the null hypothesis for each relationship. Structural equation modelling (SEM) analysis which allows the concurrent modelling of all hypothesized relationships was then applied to the measurement model using AMOS (version 23). Tests for the structural model revealed poor model fit: comparative fit index $(\mathrm{CFI})$ of 0.839 ; root mean square error of approximation (RMSEA) of 0.089; degrees of freedom 290, chi square 2103, with a p value of $<0.001$.

Reviewing the structural model (model A) whilst co-variances between the dependent variable and four of the independent variables were significant, that between normative commitment towards self-as-learner and word-of-mouth was not significant (estimate -.001; p.956). The null hypothesis had to be accepted. This could have been because the skewed distribution of the normative commitment construct undermined the potential for a relationship with the dependent variable. However, it could also be that the internal focus of normative commitment towards self-as-learner means that there is little connection between these feelings and intentions to speak positively about HE. The feelings are about self rather than the broader HE community and are therefore less relevant as a topic of conversation. There is no-one/nothing to reward or penalize. The normative commitment (NORMSELF) construct was removed. This adjustment resulted in a more parsimonious framework (model B comprising independent variables AFFIN, AFFAC, CALIN, COMBALIN) which could better explain the relationship between students' positive word-of-mouth intentions and commitment within higher education. The strength of the relationships between independent and dependent variables remained constant (table 1). 
Table 1: Structural model co-variances.

\begin{tabular}{|l|l|l|l|l|l|}
\hline Model & AFFIN & AFFAC & COMBAL & CALIN & NORMSELF \\
\hline Model A & .162 & .574 & .189 & -.088 & $-.001^{*}$ \\
CFI: 0.839 & & & & & \\
\hline Model B & .162 & .573 & .189 & -.088 & $\mathrm{n} / \mathrm{a}$ \\
CFI: 0.852 & & & & & \\
\hline
\end{tabular}

*non-significant at $\mathrm{p}<.001(\mathrm{p} .956)$

Model B therefore was the most parsimonious framework which explains the relationship between commitment and word-of-mouth in this context. The structural model provided modest levels of fit with CFI at 0.852 , chi square 1667 with 222 degrees of freedom. This final framework (model B), was supported by a series of fit indices which suggested that it was a reasonable explanation of the data and articulated theoretically sound relationships between commitment and word-of-mouth communication within HE. Some of these relationships have been previously evidenced in studies outside HE (e.g. Fullerton, 2005; Fullerton, 2011; Beatty et al., 2012) and within HE (Fazal-e-Hasan et al., 2017) but this is the first time that commitment focused at people, and commitment balance, have been shown to have a relationship with positive word-of-mouth.

\section{Testing for common method bias.}

Once Model B had been identified as the most appropriate explanation of relationships between commitment and word-of-mouth, tests for common method bias were applied. Such bias might be a result of single respondent bias due to a lack of temporal separation (Podsakoff et al., 2012) or the presence of an overarching factor which was not yet represented within the explanation of the relationship between independent and dependent 
variables (Podsakoff et al. 2003). A common factor was built into the CFA of Model B. Imputed data generated from the CFA created measured independent variables. A revised structural model with latent variables each incorporating a common factor was analysed (figure 3). The addition of the common factor improved model fit to CFI 0.975 ; the relative strengths of the four independent-dependent variable relationships remained consistent (tables 2 and 3). Affective commitment towards academics retained the strongest relationship with positive word-of-mouth with a standardised estimate of 46 . Affective commitment towards institution retained a positive but weaker relationship with positive word-of-mouth with a standardised estimate of .25 . Commitment balance retained a positive relationship with positive word of mouth with a standardised estimate of .23 . Calculative commitment demonstrated a negative but weak relationship with positive word-of-mouth with a standardised estimate of -.11. All relationships were significant at $p<.001$.

Table 2: Model fit and estimates with common factor

\begin{tabular}{|c|c|c|c|c|c|c|}
\hline \multirow[t]{2}{*}{ Model } & \multicolumn{2}{|c|}{ Model fit } & \multicolumn{4}{|c|}{ Estimates } \\
\hline & $\begin{array}{l}\text { C.F.I. } \\
(>0.92)\end{array}$ & $\begin{array}{l}\text { R.M.S.E.A. } \\
(<0.08)\end{array}$ & AFFIN & CALIN & COMBAL & AFFAC \\
\hline $\begin{array}{l}\text { Model B no } \\
\text { common factor: } \\
\text { structural model }\end{array}$ & 0.852 & 0.094 & .100 & -.090 & .280 & .570 \\
\hline $\begin{array}{l}\text { Model B with } \\
\text { common factor: } \\
\text { structural model }\end{array}$ & 0.975 & 0.629 & .250 & -.109 & 233 & .457 \\
\hline
\end{tabular}


Table 3: Regression weights Model B with common factor.

\begin{tabular}{|l|l|l|l|l|}
\hline Relationship & Estimate & SE & CR & P \\
\hline PWOM_wcf <- AFFAC_wcf & .457 & .030 & 15.054 & $<.001$ \\
\hline PWOM_wcf <- COMBAL_wcf & .233 & .043 & 5.486 & $<.001$ \\
\hline PWOM_wcf <- CALIN_wcf & -.109 & .016 & -6.904 & $<.001$ \\
\hline PWOM_wcf <- AFFIN_wcf & .250 & .036 & 6.880 & $<.001$ \\
\hline
\end{tabular}

In summary, the framework (figure 3) represented the following significant $(<0.001)$ relationships between commitment and word-of-mouth within higher education:

Figure 3: Final best fit framework (with common factor).
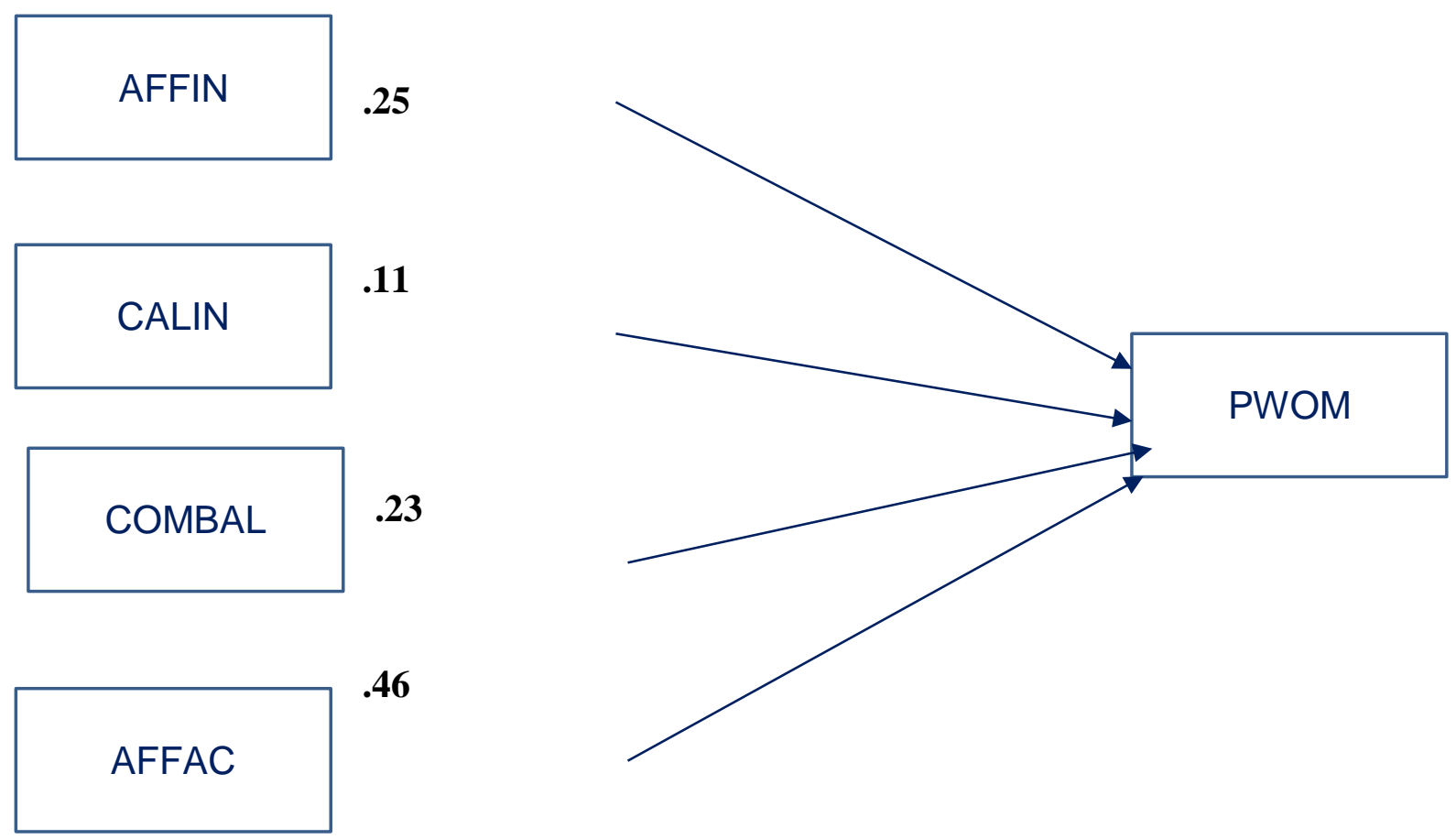

All relationships significant at $<.001$.

- A strong relationship between affective commitment towards academics and intention to emit positive word-of-mouth, reflecting much of the literature on affective commitment in contexts outside HE (e.g. Fullerton, 2005; Fullerton, 2011; Beatty et 
al., 2012) and within HE (Fazal-e-Hasan et al., 2017). However, this is novel as it is the first piece of evidence that affective commitment directed towards people drives positive word-of-mouth. Thus, hypothesis 1 is supported by the study.

- A weaker, but positive relationship between affective commitment towards institution and intention to emit positive word-of-mouth. Again, this corroborates extant scholarship which examines affective commitment alongside word-of-mouth particularly that of Fazal-e-Hasan et al. (2017). The framework suggests affective commitment towards the institution has a weak, but positive impact on students' intention to emit positive word-of-mouth. Hypothesis 2 is supported by the study.

- A positive relationship between the new construct, commitment balance and word-ofmouth. This is a new finding which reinforces the importance of reciprocated commitment within relational exchange. The framework suggests that commitment balance enhances positive word-of-mouth communication. Hypothesis 5 is thus supported.

- A weak but negative relationship between calculative commitment towards the institution and intention to emit positive word-of-mouth, corroborating the outcomes of the work of Beatty et al. (2012) and Fullerton (2011) outside HE. Hypothesis 3 is therefore supported by the study.

- As no significant relationship was discovered between normative commitment towards self-as-learner and positive word-of-mouth, hypothesis 4 was not supported by the study.

The framework supports four of the five hypotheses; table 4 provides a synopsis of these findings. There is a possibility that adaptations using the modification indices may have made this an over-fitted model which may simply reflect the idiosyncrasies of the sample (Byrne 2010). Hence this final framework which is the outcome of this study, would benefit 
from testing within new populations, to confirm its validity as a framework for commitment and word-of-mouth intentions within HE.

Table 4: Connectivity of constructs and analysis

\begin{tabular}{|c|c|c|c|}
\hline Hypothesis & $\begin{array}{l}\text { Null hypothesis } \\
\text { supported? }\end{array}$ & Analysis & New knowledge? \\
\hline H1. & No & $\begin{array}{l}\text { The affective commitment } \\
\text { experienced towards academics } \\
\text { generates a desire to reward } \\
\text { academics through positive } \\
\text { conversations with peers which } \\
\text { articulate the positive interactions } \\
\text { students have experienced. }\end{array}$ & $\begin{array}{l}\text { Corroborates } \\
\text { Fazal-e-Hasan et } \\
\text { al. (2017) study in } \\
\text { HE. }\end{array}$ \\
\hline $\mathrm{H} 2$. & No & $\begin{array}{l}\text { Positive feelings associated with } \\
\text { affective commitment results in } \\
\text { students' attempts to reward the } \\
\text { institution through positive word-of- } \\
\text { mouth. Positive feelings captured } \\
\text { through affective commitment } \\
\text { enable positive stories to be shared. }\end{array}$ & $\begin{array}{l}\text { Corroborates } \\
\text { Fazal-e-Hasan et } \\
\text { al. (2017) study in } \\
\text { HE. }\end{array}$ \\
\hline H3. & No & $\begin{array}{l}\text { Commitment based on the penalty } \\
\text { of departure, results in students } \\
\text { with-holding positive stories in an } \\
\text { attempt to assert some control in a } \\
\text { situation characterised by students' } \\
\text { perceived lack of power to exit. } \\
\text { Perceived costs may inhibit positive } \\
\text { experiences and therefore stories to } \\
\text { share. }\end{array}$ & $\begin{array}{l}\text { New knowledge } \\
\text { corroborating } \\
\text { studies outside HE } \\
\text { (e.g. Harrison- } \\
\text { Walker, 2001; } \\
\text { Fullerton, 2011; } \\
\text { Beatty et al., } \\
\text { 2012). }\end{array}$ \\
\hline $\mathrm{H} 4$. & Yes & $\begin{array}{l}\text { The internal focus of normative } \\
\text { commitment represents feelings } \\
\text { about self rather than the broader } \\
\text { HE community and is a less } \\
\text { relevant, possibly inhibited topic of } \\
\text { conversation. }\end{array}$ & $\begin{array}{l}\text { New knowledge } \\
\text { corroborating } \\
\text { literature outside } \\
\text { HE with an } \\
\text { external focus for } \\
\text { commitment (e.g. } \\
\text { Fullerton, 2011). }\end{array}$ \\
\hline H5. & No & $\begin{array}{l}\text { Students seek to penalize or at least } \\
\text { not to proactively help an institution } \\
\text { which they perceive is not } \\
\text { reciprocating to them equitably. } \\
\text { Students' perception of an equitable } \\
\text { balance of commitment between } \\
\text { them and their institution enhances } \\
\text { the likelihood of students engaging } \\
\text { in positive word-of-mouth. }\end{array}$ & New knowledge. \\
\hline
\end{tabular}


Thus, research objective 2 finds that students' intentions to speak positively about HE are predominately influenced by affective commitment, in particular affective commitment towards the academics with whom students study. Calculative commitment has a small but significant negative effect on word-of-mouth. Whilst there is evidence that normative commitment is experienced within $\mathrm{HE}$, there is no evidence that it influences positive wordof-mouth. Finally, the notion of commitment balance appears to be a credible construct which is both evident and relevant to higher education, but also has an impact on word-of-mouth.

\section{Limitations}

Whilst this study provides clear outcomes it is important to consider these through the lens of validity. Considerable effort was placed into generating valid data, however the study is more robust with an acknowledgement of its limitations. Validity was considered throughout the research process during research design, research implementation and data analysis (Cohen et al. 2007).

Whilst this study sought to gather data from a number of modern universities it is acknowledged that the convenience sampling approach undermines the validity and generalisability of the results. Response rates across the four institutions varied from $7 \%$ to $31 \%$ of the estimated sample of students approached. This variation appeared to be related to the methods of survey distribution permitted by gatekeepers. Whilst clear instructions were given to all gatekeepers, those gatekeepers were ultimately in control of questionnaire distribution; and it was ultimately difficult to judge the non-response error.

The limitations of surveys as reductionist approaches to data collection are acknowledged as is the lack of control over their completion by participants. Both can undermine validity. The requirements to keep the survey completion to under ten minutes, 
limited complexity of commitment foci. Given the importance of the finding that affective commitment towards academics has the strongest relationship with positive word-of-mouth, such complexity may indeed be worthy of future study.

The study is based upon latent variables the measures for which were drawn from previous studies (e.g. AFFAC) or developed specifically for this study (e.g. COMBAL) and determined through exploratory factor analysis on pilot data. Cronbach Alpha analysis demonstrated reliable scales for all but one latent variable. Calculative commitment towards institution (CALIN) was the only problematic latent variable, with a 0.667 Cronbach Alpha falling short of the expected 0.7 limit. Thus, dismissal of the null hypothesis for $\mathrm{H} 3$ is arguably the least robust analytical judgement. Indeed, we note that CALIN sits at the bottom of the hierarchy of commitment (figure 2), lower than might be theoretically expected; this may be a reflection of scale validity. However, the significant, weak, negative relationship with positive word-of-mouth found here, is in line with studies outside HE (Fullerton, 2011; Beatty et al., 2012).

Cross-validation was conducted on the dataset to explore the stability of the fit and estimate outcomes. The dataset was split into three random groupings each comprising approximately 380 participants. Whilst fit remained stable across the three random samples, estimates were less stable. A consistent strong positive relationship between affective commitment towards academy (AFFAC) and word-of-mouth (PWOM) was evident across all three samples. Relationships between other independent variables and word-of-mouth were less stable, although the AFFAC-PWOM relationship was consistently the strongest relationship. Therefore, the strong relationship between affective commitment towards academics (AFFAC) and positive word-of-mouth appears to be the outcome from the framework with the highest levels of validity. 
Finally, in terms of the analysis of data, whilst the conceptual framework was developed to articulate relationships between commitment-based latent variables as independent variables and positive-word-of-mouth as the dependent variable, it is important to remember that the relationships identified from estimates are correlations rather than causal given the cross-sectional nature of the research.

\section{Discussion and implications}

This work provides evidence that students' positive conversations about HE are most likely to be stimulated by an ongoing positive connection with their academic tutors. Such positive stories may enhance student recruitment if conducted externally and may enhance the student experience if they take place within the university. If universities are keen for their students to be telling positive stories about higher education experiences, then they should work with their academics to create an environment which values students and promotes ongoing affective connections between students and academics.

The outcomes of this analysis of undergraduate students' experiences within modern universities, re-emphasise the importance of people within the context of relational exchange. Students want to work with academics who care. It is critical that Universities consider the characteristics of academics which foster commitment from students based upon enjoyment, caring and inspiration. Institutions should reward those academics who generate affective commitment amongst the student cohort. Pedagogic strategies should embrace the opportunities to deploy these characteristics within the learning process. One-to-one tutorials, even if brief, can provide the underpinning for affective commitment between academics and students to thrive and empower learning. The uncertainties which learners experience during the learning process may be why these qualities are particularly valued. These outcomes 
corroborate Hansen et al.'s (2003) findings outside HE, that affective commitment towards employees has an important role to play within the relational context. In this study, the extent of affective commitment felt by students towards the institution was higher than that towards academics (see figure 2) but importantly it was affective commitment towards academics which was the far stronger driver of positive word-of-mouth. Whilst the study doesn't provide the reason for this outcome, we can theorise that building students' connections with people may be more challenging than building connections with the institution. The array of tutors with whom students have contact is often very broad, contact with many of these tutors may be limited with little ongoing face-to-face interaction to stimulate affective commitment. In other circumstances, say supervisory relationships, connections may be strong and deep. When such connections are established they are powerful. In contrast the institution has an array of reasonably stable devices to use to build affective commitment including its branding, location, estate and reputation. These devices are less people-focused and therefore more controllable. But perhaps the resulting institutionfocused commitment is less meaningful. So, it is possible to suggest that whilst affective commitment to institution (AFFIN) may be easier to develop amongst students, it doesn't have the same potency in generating positive conversations, as does the affective commitment students experience towards those people who provide support during the academic journey.

The study shows that whilst calculative commitment was experienced by students and did have an impact on positive word-of-mouth, the extent to which it was reported and the strength of its impact were smaller than anticipated at the outset of this research. The limitations noted the potential impact of scale validity on this result.

The study introduced the idea of normative commitment towards self-as-learner. This was distinctive in that the focus of commitment was internal rather than external. 
Descriptive data showed that it was a strongly felt form of commitment and is therefore worthy of consideration in future research. However, there was no evidence that students' positive word-of-mouth is impacted by normative commitment. Whilst previous studies (e.g. Fullerton, 2011; Beatty et al., 2012) have found weak relationships between word-of-mouth and normative commitment, this might be explained by their external focus of normative commitment.

Finally, the concept of commitment balance, appears to resonate and have impact within students' reports of their experiences of HE. It is important that institutions consider carefully how they can demonstrate their reciprocal commitment to the students who spend three or four years studying with them.

\section{Managerial Implications.}

The importance of affective rather than calculative commitment amongst undergraduate students, is a finding which should give institutions the confidence to engage with their students in a relational manner. It provides support for a relational approach to students, conceptually and in practice. The implications of investment in affective commitment demand a move to a more personalised approach. Small group and tutorial contact with academics are likely to generate affective commitment, but clearly this a more resource intensive approach to delivery than that of the large lecture theatre. Nevertheless, it is important that pedagogic strategies embrace one-to-one interaction with students which can stimulate these relational connections. Alongside the scale of contact are the characteristics of academic tutors. Universities need to recruit academics who want to work with students and demonstrate characteristics associated with affective commitment including caring, belonging and inspiring. Such characteristics should be incorporated within recruitment person 
specifications. Once recruited, inspiring and caring academics can be usefully used within student recruitment open days and more general university fairs. Sample lectures are not just helpful in terms of displaying content to prospective students, but also start to convey the nature of the relationship between tutor and students. Such connections can be fostered within one-to-one conversations. Open days should devote time to articulating and evidencing the nature and importance of relationships between academics and students. It is of course essential that such connections are inclusive and authentically flow through the student experience. Future research might measure academics' contributions to the recruitment process and assess their impact on students' commitment, satisfaction, retention, engagement and achievement.

Whilst the investments required in promoting such approaches are significant, these may be offset by the benefits of word-of-mouth on recruitment within an increasingly competitive sector with decreasing applications (UCAS 2017).

The implication of commitment balance for practice is the need for recognition that commitment is not just something you seek, you must also reciprocate. Recruitment strategies including prospectuses and open days should seek to communicate and demonstrate commitment towards prospective students.

\section{Future research.}

There is clearly an opportunity to take this framework and test it within a broader population both within the UK, but also in international contexts. Re-examination of the framework would make sense in the UK as cohorts of undergraduate students are now subject to higher fees than this study's sample. Replication studies should consider issuing a stringent set of instructions to survey managers so that data is collected in the same manner at 
all institutions (e.g. solely distributed through the portal) with the aim of producing a more homogeneous result. This action might reduce the variation by institution.

Key criteria which are considered important within the educational experience such as class size and extent of student/tutor interaction could be examined in future studies using this framework. A future study could compare the potency of forms/foci of commitment on positive word-of-mouth amongst undergraduate and postgraduate students. Undergraduate cohorts may exhibit lower levels of commitment balance than their postgraduate peers.

Indeed, commitment balance emerges as worthy of future study. Future research could embrace further exploration into this new construct within HE. Research might examine commitment balance alongside additional loyalty and co-operation based consequences associated with commitment in the literature (Morgan and Hunt, 1994; Bendapudi and Berry, 1997; Hening-Thurau et al., 2001; Hansen et al., 2003; Fullerton, 2005; Gustafsson et al., 2005; Rojas-Mendez et al., 2009).

Finally, this study focusses on positive word-of-mouth as a relational outcome of commitment; it would be interesting to examine the impact of commitment on negative wordof-mouth and silent endurance as have Beatty et al., (2012) outside the context of higher education.

Therefore, this research provides evidence that students experience commitment within the context of HE and highlights commitment's capability to stimulate positive stories about higher education. Such positive communication can both enhance the student experience for current students and contribute to recruitment strategies for the students of the future. 


\section{References.}

Allen, N., J. and Meyer, J., P. (1990). The measurement and antecedents of affective, continuance and normative commitment to the organisation. Journal of Occupational Psychology, 63, 1-18.

Author/s (2019) Journal of Further and Higher Education.

Beatty S., E., Reynolds, K.,E., Nobel S.,M. and Harrison, M.,P., (2012) Understanding the relationships between commitment and voice: Hypotheses, empirical evidence, and directions for future research. Journal of Service Research 15(3), 296-315.

Bendapudi, N. and Berry, L., L. (1997). Customers' motivations for maintaining relationships with service providers Journal of Retailing, 73(10),15-37.

Breitsohl, H., and Ruhle, S., A. (2016) The end is the beginning-The role of residual affective commitment in former interns' intention to return and word-of-mouth. European Journal of Work and Organizational Psychology, 25(6), Nov, 2016, 833848.

Brown, T., J., Barry, T., E., Dacin, P.,A. and Gunst, R.,F., (2005). Spreading the word: Investigating antecedents of consumers' positive word-of-mouth intentions and behaviours in a retailing context. Journal of the Academy of Marketing Science. $33(2), 123-138$.

Byrne. B., M. (2010). Structural Equation Modelling with A.M.O.S.: Basic concepts, applications and programming (second edition). Routledge, New York.

Cohen, L., Manion, L. and Morrison, K. (2007). Research Methods in Education (sixth edition) Routledge, Abingdon.

De Matos, A. and Rossi. C. (2008). Word-of-mouth communications in marketing: a metaanalytic review of the antecedents and moderators. Journal of the Academy of Science. 36, 578-596. 
Evanschitzky, H., Brock, C. and Blut, M. (2011). Will you tolerate this? The impact of affective commitment on complaint intention and post-recovery behavior. Journal of Service Research 14(4), 410-425.

Fazal-e-Hasan, S., M., Lings, I., Mortimer, G., and Neale, L. (2017). How gratitude influences customer word-of-mouth intentions and involvement: the mediating role of affective commitment. Journal of Marketing Theory \& Practice. Spring2017, Vol. 25 Issue 2, 200-211.

Fullerton, G. (2011). Creating advocates: The roles of satisfaction, trust and commitment Journal of Retailing and Consumer Services: 18, 92-100.

Fullerton, G. (2005). How commitment both enables and undermines marketing relationships. European Journal of Marketing, 39 (11/12), 1372-1388.

Greenacre, L., Freeman, L., Cong, K., and Chapman, T. (2014) Understanding and predicting student Word of Mouth. International Journal of Educational Research 64, 40-48.

Gruen, T., W., Summers, J., O. and Acito, F. (2000). Relationship marketing activities, commitment and membership behaviors in professional associations Journal of Marketing 64 (July), 34-49.

Gundlach, G., T., Achrol, R., S. and Mentzer, J.,T. (1995). The structure of commitment in exchange Journal of Marketing, 59 (January), 78-92.

Gustafsson, A., Johnson, M., Roos, I. (2005). The effects of customer satisfaction, relationship commitment dimensions and triggers on customer retention Journal of Marketing. 69 (4), 210-218.

Hair, J., F., Black, W., C., Babin, B.,J. and Anderson, R.,E. (2010). Multivariate Data Analysis (seventh edition), Pearson, New Jersey.

Hansen, H., Sandvik, K. and Selnes, F. (2003). Direct and indirect effects of commitment to a service employee on the intention to stay Journal of Service Research 5(4), 356-368. 
Harrison-Walker, L., J. (2001). The measurement of word-of-mouth communication and an investigation of service quality and customer commitment as potential antecedents. Journal of Service Research, 4 (1), 60-75.

Hayes, T., J. Ruschman, D. and Walker, M.,M. (2009). Social networking as an admissions tool: a case study in success Journal of Marketing for Higher Education, 19(2), 109124.

Helgesen, O. and Nesset, E. (2007). Images, satisfaction and antecedents: Drivers of student loyalty? A case study of a Norwegian University College Corporate Reputation Review 10(1), 38-59.

Helgesen, O. (2008). Marketing for Higher Education: A Relationship Marketing Approach. Journal of Marketing for Higher Education. 18(1), 50-76.

Hennig-Thurau, T., Langer, M., F. and Hansen, U. (2001). Modeling and managing student loyalty - an approach based on the concept of relationship quality Journal of Service Research 3 (4), 331-344.

Herold, K., Tarkiainen, A., and Sundqvist, S. (2017). How the source of word-of-mouth influences information processing in the formation of brand attitudes. Journal of Marketing for Higher Education, Jan-Jun2016, Vol. 26 Issue 1, 64-85.

Herold, K. and Sundqvist, S. (2013). The role of word-of-mouth activity and information diagnosticity in the formation of higher education applicants' attitudes. American Marketing Association, winter 2013, 269-270.

Jones, T., Taylor, S., F. and Bansal, H.,S. (2008). Commitment to a friend, a service provider, or a service company_ are they distinctions worth making? Journal of the Academy Marketing Science. (2008) 36, 473-487. 
Kara, A. and de Shields, O., W. (2004). Business student satisfaction, intentions and retention in higher education: An empirical investigation, $M E G$ (Fall 2004).

Lacey, R., Suh, J. and Morgan, R. (2007). Differential effects of preferential treatment levels on relational outcomes Journal of Service Research 9(3), 241-256.

Li, C., and Wang, X, (2010). How does online word-of-mouth influence students' course selections and their attitudes towards professors? American Marketing Association, Winter 2010.

Meyer, J., P. and Parfyonova, N., M. (2010). Normative commitment in the workplace: A theoretical analysis and re-conceptualisation. Human Resource Management Review 20(4), 283-294.

Moorman, C., Zaltman, G. and Despande, R. (1992). Relationships between providers and users of marketing research: the dynamics of trust within and between organisations Journal of Marketing Research. 29 (August), 314-329.

Morgan, R. and Hunt, S. (1994). The commitment-trust theory of relationship marketing. Journal of Marketing. 58, (3), 20-38.

Patti, C., H. and Chen, C.,C. (2009). Types of word-of-mouth messages: Information search and credence-based services Journal of Promotion Management 15, 357-381.

Rojas-Mendez, J., I., Vasquez-Parraga, A., Z., Kara, A. and Cerda-Urrutia, A., (2009). Determinants of student loyalty in higher education: A tested relationship approach in Latin America Latin American Business Review 10, 21-39.

Sharma, N., Young, L. and Wilkinson, I. (2006). The commitment mix: Dimensions of commitment in international trading relationships in India. Journal of International Marketing, 14 (3), 64-91.

Sipilä, J., Herold, K., Tarkiainen, A., and Sundqvist, S. (2017) The influence of word-ofmouth on attitudinal ambivalence during the higher education decision-making process Journal of Business Research November 2017 80, 176-187. 
Southcombe, A., Fulop, L. and Carter, G. (2015). Building commitment: an examination of learning climate congruence and the affective commitment of academics in an Australian University. Journal of Further and Higher Education, 39 (5), 733-757.

Sun, T., Ayoun, B. and Calhoun, J. (2013). The effect of organisational commitment on word-of-mouth intentions in recruitment in China Journal of Human Resources in Hospitality and Tourism, 12, 192-216.

Taylor, D., G. (2009). 'Psst, about that Prof': College students' word-of-mouth, instructor evaluation and course selection. American Marketing Association, Winter 2009, 391396.

UCAS (2017) Applicants for UK higher education down: 5\% for UK students and 7\% for EU studentshttps://www.ucas.com/corporate/news-and-key-documents/news/applicants$\underline{\text { uk-higher-education-down-5-uk-students-and-7-eu-students }}$

Wardley, L., Belanger, C. and Valorie, L. (2013). Institutional commitment of traditional and non-traditional-aged students: a potential brand measurement? Journal of Marketing for Higher Education 23(1), 90-112.

Wong, H. and Wong, R. (2012). Relationship commitment in self-financed higher education International Journal of Business and Management, 7(7),15-23. 